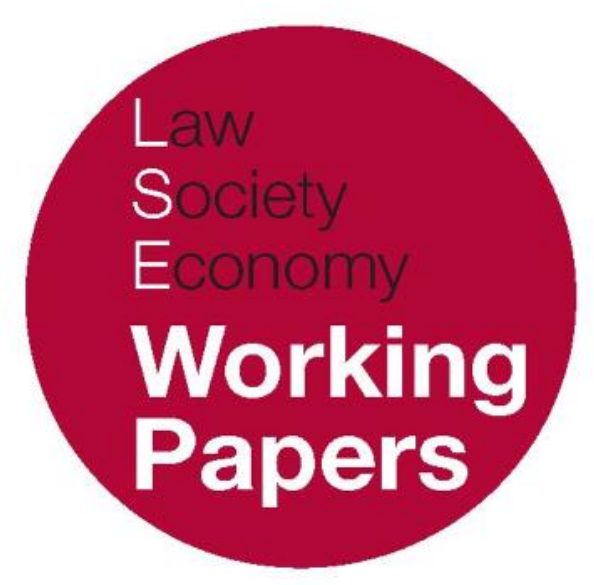

\title{
Constitutionalising Regulatory Governance Systems
}

\author{
Julia Black \\ LSE Law, Society and Economy Working Papers 02/2021 \\ London School of Economics and Political Science
}

Law Department

This paper can be downloaded without charge from LSE Law, Society and Economy Working Papers at: www.lse.ac.uk/collections/law/wps/wps.htm and the Social Sciences Research Network electronic library at: https://ssrn.com/abstract=3813812.

(C) Julia Black. Users may download and/or print one copy to facilitate their private study or for non-commercial research. Users may not engage in further distribution of this material or use it for any profit-making activities or any other form of commercial gain. 


\title{
Constitutionalising Regulatory Governance Systems
}

\author{
Julia Black*
}

\begin{abstract}
How to ensure, in democratic states, that those to whom power has been delegated act in line with constitutional norms and values is a perennial, and much explored, question. This article suggests that in analysing how constitutional actors seek to govern regulatory institutions we should 'flip' the perspective, and not just look (down) at regulatory systems from a constitutional perspective, but also look (up) at constitutions from a regulatory perspective. This flipped perspective will be used to conceptualise constitutions not from the starting point of established constitutional, legal or political theory but from a particular regulatory theory, that of decentred or polycentric regulation, and to explore the different ways in which 'regulators are regulated' through the interplay of the constitutional governance system with the regulatory systems it creates. We can thus think of a constitutional governance system as both constituting and regulating, or constitutionalising, a regulatory system through the goals and values each seeks to pursue, the techniques, organisations and individuals through which each acts, the particular sets of ideas or cognitive and epistemological frameworks those actors bring, and with a continual need both for, and in constant pursuit of, trust and legitimacy in the eyes of those on whose behalf they purport to govern.
\end{abstract}

\footnotetext{
* Professor of Law, London School of Economics and Political Science. Email: j.black@lse.ac.uk. I am grateful to Christie Ford, Carol Harlow, Tom Poole and Rick Rawlings for comments on an earlier draft of this paper. All responsibility for views, errors and omissions remains my own.
} 


\section{INTRODUCTION}

One of the features, and for some the frustrations, of the increasing roles taken on by modern democratic states is that, for functional reasons, those who have been elected into power need to delegate day to day responsibility for that myriad of activities, leading to the growth of the administrative and, its close cousin, the regulatory state (see eg Majone 1994; Gilardi et al 2006; Harlow and Rawlings 2021; Yeung 2010). As the role and powers of regulators have grown, so has greater attention been paid to their role in constituting, not just administering, the regulatory systems which govern the activities of both public and private actors. For constitutional scholars, regulatory agencies can have the disadvantage of blurring the separation of powers, acting as both rulemaker and executive decision maker, and often as enforcer as well. Further, although state-based regulators are legally charged with achieving the goals set out for them by governments in line with the powers they have been given, regulators, as both individuals and organisations, wield power over significant swathes of public and private life. Mistrust in the manner in which, and effectiveness with which, they perform their roles can be prevalent, all the more so in an era of populism. Thus in democratic states, at least, there is a continual debate as to how much power should be delegated to regulators, who should be involved in their decision making, how they should be called to account, by whom and with what consequences.

Therefore, it is critically important to address the question of how to ensure that those exercising regulatory powers and functions act in line with constitutional norms and values. This is a challenge which is usually framed in terms of how to call regulators to account. There are many excellent accounts which examine this question (eg Bovens 2007; Dowdle 2006). This article takes a slightly different approach. It argues first, that we broaden out the issue from one of accountability to one of regulation; in the well-worn phrase, the question really is 'who regulates the regulators', not just who calls them to account. Second, it argues that if we recognise that, amongst the many roles that constitutions have, they establish systems of governance for the legal and political ordering of the institutions of the state, they share characteristics of systems of regulatory governance. As such, it is suggested that they can be analysed using the framework set out below, as can their interactions with those they seek to regulate.

The article proceeds in three main parts. The first explains what is meant by constitutional governance systems and their role in constitutionalising regulation in the context of the state. The second sets out a framework for analysing regulatory systems, and some of the underlying assumptions on which it is based. The third uses the framework to explore the different elements of constitutional governance systems and the nature of the interactions between those systems with the regulatory systems they are seeking to regulate, or as termed here, to 'constitutionalise'. 


\section{THE ROLE OF CONSTITUTIONAL GOVERNANCE SYSTEMS IN CONSTITUTIONALISING REGULATORY SYSTEMS}

A constitutional governance system here refers to the institutional structures, norms and values which derive directly or indirectly from the constitution, and/or from core institutions which are founded by the constitution, notably the legislature, executive and judiciary, and which are directed at ensuring that both the institutions of the state and the regulatory systems which operate within the state do so in line with those constitutional norms and values. The focus here will be on those elements which are directed particularly at those regulatory organisations which have been created by the state and/or to whom the state has delegated powers, or other actors who the state recognises as exercising powers of such import or in such a way that the same or similar constitutional norms and values should apply to them.

'Constitutionalising' regulatory systems may mean any of at least three things: first, it could mean elevating a regulatory system to having constitutional status - literally enshrining it in the constitution. Thus a Bill of Rights might be enshrined in a constitution, as might the organisation(s) which are charged with ensuring its provisions are upheld on an ongoing basis (eg a specialist agency, in addition to the executive, legislature and judiciary). That would render the Bill and related agency distinct in status from a statute which defines human rights and creates a specialist institution responsible for promoting adherence to them, as is currently the case in the UK and (to some extent) the Equality and Human Rights Commission, for example. Alternatively, constitutionalising regulatory systems could mean ensuring that public or private regulatory systems operating within the state, which may be created by legislation or by self-regulatory systems set up by professions or industry, operate in line with the constitutional norms and values of that state. Thirdly, constitutionalising regulatory systems could mean seeking to ensure that those regulatory systems which operate outside a state - whether set up by international law or operating entirely outwith any legal structure (such as transnational regulators) conform to some set of norms and values which are akin to those which might be found within a constitutional 'ideal type', often but not necessarily, of a liberal democratic state (see eg Kingsbury et al 2005; Harlow 2006; Krisch 2010; Ladeur 2012).

Each of the three definitions is suitable for different purposes. It is the second sense of 'constitutionalising' regulatory systems which is used here, viz ensuring regulators within the state act in line with the constitutional norms and values of the state in which they operate. Thus the focus is on how the system of constitutional governance constitutionalises regulatory systems.

Why use the terms 'constitutional governance system' and 'constitutionalising' to describe this activity, rather than regulation, or accountability, or even public or administrative law? The answer is threefold. First, because characterising the institutional norms and structures in place to ensure that regulators act in line with constitutional values as a 'constitutional governance system' prompts us to ask how the constitutional state functions as a regulatory system within itself - what are the legal and non-legal mechanisms by which the constitution is 'self-enforced' in this regard? Second, the characterisation of a 'constitutional governance system' draws attention to the disaggregated institutional 
nature of the state - going well beyond the 'core' institutions of the legislature, judiciary and executive and its accompanying departments of state, out into the 'periphery': to the world of that multitude of organisations which have varying degrees of independence from the executive and comprise the regulatory and administrative parts of the state. Third, because the characterisations of both 'constitutional governance system' and 'constitutionalising regulatory systems' provide wider lenses through which to analyse the relationship between those two systems than is provided by simply focusing on ex post accountability, though that is of course important.

Although this conceptualisation of constitutions and the analysis which follows is unusual in deriving not from established constitutional, legal or political theory but from a particular regulatory theory, that of decentred or polycentric regulation, there is nothing new in saying that constitutions both constitute and regulate the exercise of legal and political power (see eg Raz 1998). Further, it is not to say that constitutional governance systems are 'just' another form of regulatory governance. Clearly they are not: constitutions constitute states and their governing institutions, they transform a collective into a polity and set out the ultimate principles to which all in that society must conform, including those occupying the core institutions of the state which the constitution creates, thus occupying an 'apex' position in the legal hierarchy. To that extent, the characterisation and analysis of 'constitutional governance systems' does not disrupt the fundamental role of constitutions themselves in the creation and functioning of the state, and 'administrative law is [still] constitutional law writ small' (Dyzenhaus 2016, p. 24). But it is suggested that in analysing how constitutional actors seek to govern regulatory institutions we 'flip' the perspective, and do not just look (down) at regulatory systems from a constitutional perspective, but also look (up) at constitutions from a regulatory perspective. Pursuing that analysis to its fullest extent would take us beyond the realms of the main focus of this article. But this flipped perspective will be used to explore the different ways in which 'regulators are regulated' through the interplay of the constitutional governance system with the regulatory systems it has created, ways which include but go beyond systems of accountability.

\section{ANALYSING REGULATORY GOVERNANCE SYSTEMS}

\section{DeCentred or Polycentric Conception of Regulatory Governance Systems}

Given the centrality to this analysis of regulatory governance systems, it is worth taking some time to set out how such systems are being conceived here. Regulation, or regulatory governance, is understood here as a series of intentional, sustained and focused attempts to change the behaviour of others in order to pursue a collective purpose, using a range of techniques which often, but not always, include a combination of rules or norms and some means for their implementation and enforcement (Black 2001; Koop and Lodge 2017). Regulation can focus on any area of social or natural activity, from how wars are conducted to how buildings are constructed. Regulation may involve a high degree of state 
involvement, or none at all, or involve both state and non-state actors in various ways, each of whom may use legal and/or non-legal norms. Thus regulation is a mode of governance not just of government, and the terms 'regulatory system' and 'regulatory governance system' will be used interchangeably.

Regulation is an activity which can be performed by a range of individuals and organisations. Those participating in that common regulatory project may be sufficiently interrelated to form a system, regime or network, the boundaries of which are delineated by the definition of the project which they are engaged in pursuing, and which has some continuity over time. Regulatory systems can range in their polycentricity, ie in the degree of dispersal and fragmentation of actors in the system (regulators, regulatees, intermediaries etc), in their degree of internal coherence and connectivity, and in the extent to which they are clearly delineated. Importantly, both state-based and non-state based systems are all polycentric to varying degrees - it is not the case that centric $=$ state, and polycentric $=$ non-state

Further, those participating in, and thus constituting regulatory systems (as individuals or organisations) are independent agents, each with their own normative or value frameworks. They also have different cognitive frameworks, they rely on different sources of knowledge, have different capacities for action, have different sources of social, political, legal and economic capital, and, relatedly, different degrees of power and/or authority, all of which can affect their behaviours, roles, interests or views, and their interactions with others.

Regulatory systems are also dynamic, continuously evolving, constantly being reconstituted, redesigned and reformulated in the process of their performance. Regulators, including state-based ones, are active not passive participants in the system's evolution. Indeed, putative or existing regulators (as individuals and as organisations) may even be influential in shaping the rules which confer on them or adjust their powers and remit. Further, regulatory systems are embedded in different social, cultural, political, legal, economic and market systems with which they interact, and as such are characterised by complex internal and external interactions and interdependencies both within themselves and with other regulatory systems. Finally, in order to function effectively, all regulators, even state-based ones, have actively to create their own legitimacy, trustworthiness and authority, an important point to which we will return.

\section{CORE ELEMENTS OF REgULATORY SySTEMS: A FrAMEWORK FOR ANALYSIS}

Constitutionalising regulation means ensuring that those exercising regulatory powers and functions within a regulatory system do so in line with constitutional norms and values. As the foregoing already indicates, however, regulatory systems can be rather difficult to navigate both for participants and observers. Not least because, although regulation itself is an intentional and purposive activity, and as such involves an element of design, concrete regulatory systems are living social systems, meaning there are natural limits to the extent to which they will function over time and space in the way either their designers or participants anticipate. So the question is, how can we analyse a dynamic regulatory system, 
either 'objectively' from the external standpoint of an observer, or interpretively from the 'internal' viewpoint of different participants?

Building out from the decentred or polycentric analysis of regulatory systems set out above, I suggest we should think of regulation as a particular form of social system with six key elements, all of which constantly interact to produce a dynamic system. The analytical framework set out below takes inspiration from institutional theories but is not completely aligned with any one of them (for review see Greenwood et al 2017; Baldwin, Lodge and Cave 2012). Moreover, because it is specifically focused on analysing regulatory governance regimes it includes elements, such as technologies of governance, which these theories do not. It could thus be described as its own bespoke form of 'regulatory institutionalism'.

Figure 1: Regulatory systems - an analytical framework

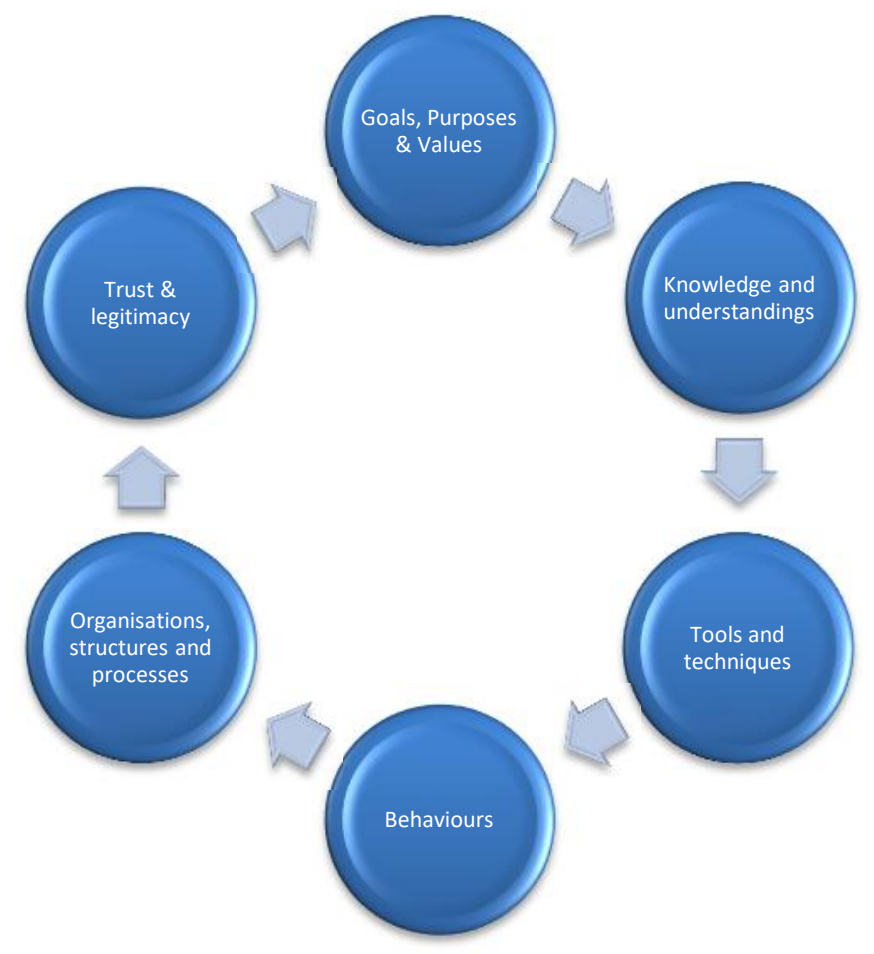

\section{Goals, Purposes and V alues}

A logical starting point is with goals, purposes and values - what is the common project the regulatory system is trying to achieve, and which values is it trying to attain or uphold in the pursuit of that project? Regulation is an inherently purposive activity, and as statebased regulatory systems are created to enable the state to pursue its goals, it is an inherently political one. However, the ideologies of neo-liberalism had a profound effect on a swathe of regulatory practice and scholarship, as it deliberately restricted the legitimate role of the state in the economy to that which was necessary to enable markets to function. 
Thus, since the 1980s, the standard economic justification for regulation prevalent in liberal democracies such as the US and UK is that the purpose of regulation is to correct market failures in order to achieve a particular model of economic efficiency. However, even the economic regulators created by the UK government at the apotheosis of neoliberalism's influence on policy were soon given additional, 'social' goals to achieve, such as universal service provision. Although the 'market perfecting' justification is influential, the purposes for which regulatory systems have been developed by the state have historically always been about managing the behaviour of both public and private actors to achieve socially defined goals, goals which extend well beyond perfecting markets (for review, see Baldwin, Lodge and Cave, 2012). Those goals include managing risks to health, safety, or the environment, facilitating coordination, or managing scarce resources. Regulation can also be aimed at controlling the power of particular social, political or economic groups, and at upholding rights and values such as principles of equality, nondiscrimination, employment rights, freedom of speech, privacy, the rule of law and the administration of justice.

Moreover, the purposes and values of any regulatory system may, and likely will, morph over time as governing coalitions come and go. Incremental changes to the system can be introduced to reflect new orientations for the regulatory project which are simply overlain on existing ones, creating potential tensions between them. Alternatively, goals may be left strategically uncertain and inchoate to facilitate the agreement of a political bargain, or, as a matter of design, to enable more experimentalist forms of governance, in which regulatory systems in different regions are allowed to experiment with ways to more closely define and achieve particular goals (Sabel and Zeitlin 2008).

\section{Knowledge and Understandings}

The second element of any regulatory system is the knowledge and understandings of actors within it, particularly but not exclusively those who are influential in shaping its design and operation, whether as regulators or otherwise. It is their cognitive frameworks and their epistemologies: how they perceive and interpret the world around them; which sources of knowledge they see as valid and relevant, and so are drawn on in constructing and reinforcing those cognitive frameworks (see eg Scott 1999; Jasanoff et al 2001; Black 2013). It is also their ideas of the purposes they are meant to be achieving, of the dynamics of the area of social life in which they are intervening (eg markets, organisations, individuals), of the physical or material properties of things and the interaction of humans with them (eg the natural environment, digital technology) (see eg Law 1986), and indeed of the properties of the regulatory system itself, including the techniques they are using (see eg Miller 2001; Power 1995; Callon and Muniesa 2005).

The importance of analysing knowledge and understandings is particularly, though not uniquely, evident when the focus of a regulatory regime is on managing risks, as there is often significant contestation as to whether a risk exists and, if so, of what nature and scale (see eg Hood, Rothstein and Baldwin 2001; Beck 1992). The highly differential national and regional responses to the continually emerging risks of Covid-19 provide a good example. The genome sequence of Covid-19 was made available globally by China in mid-January 2020. Faced with the same data, countries which had experienced SARS, 
such as China and South Korea, concluded Covid-19 was similar to SARS; in contrast, countries which were more familiar with flu, such as the UK, concluded it would be similar to flu. It was a classic example of the 'duck/rabbit' illusion - a drawing which to some looks like a rabbit, to others like a duck (https://www.illusionsindex.org/i/duck-rabbit). The same data was perceived very differently. There are a myriad of reasons for the differential responses of countries to Covid-19, particularly in the early days, but the differential understanding of the risks arising from differential interpretations of the same data is fundamental to explaining them. Important also are differential attitudes to risk. Where there is uncertainty or risks are relatively unknown, fundamental differences can arise as to what the approach of a regulatory system should be, based in turn on differences in risk tolerances: should regulators adopt a precautionary approach, prohibiting or closely regulating a product or activity until a certain level of assurance is achieved as to the risks it poses, or should it allow the product or activity, or regulate it only lightly, relying on the ability to remediate any damage that may be done if the risk crystallises? Often these questions involve highly technical and scientific assessments, but the dominance of a scientific cognitive framework can exclude other cognitive frameworks, such as those of ethics. The debate on gene editing is a good example - just because something is scientifically possible does not mean it is ethically acceptable (see eg Nuffield Council on Bioethics 2016). The dominance of a particular model of scientific epistemology can also exclude evidence from those who are not part of the accepted scientific community in the determinations (political or otherwise) of what constitutes 'valid' knowledge - and power structures will often dictate who chooses what and how to know. As a result, multiple proposals have been made for how to include a wider set of knowledge, perspectives and experiences in how regulation is framed and performed (see eg Brown 2009; Jasanoff 2017).

\section{Regulatory Techniques}

How those involved in the design and performance of regulatory systems perceive the world they operate in and the problems they have to address (and the acceptability of any solutions they may devise) is fundamental to the third element of regulatory governance systems: the design and operation of regulatory techniques, or technologies of regulation. There are multiple forms and combinations of regulatory techniques, giving rise to multiple categorisations, in which 'command and control' styles (detailed legal rules backed by legal sanctions) are contrasted with other 'new governance' forms of regulation: principlesbased, outcomes-focused, management-based, process-based, experimentalist, anticipatory, responsive and so forth (for review see Baldwin, Cave and Lodge 2010 and 2012).

In essence, the broad suite of regulatory techniques includes but is not limited to legal or non-legal norms (principles, standards, codes, guidance and so forth); methods for detecting, monitoring, auditing and certifying; liability rules for those causing harm; and sanctions for non-compliance. It includes calculative models (eg for calculating prices, the spread of diseases, assessing risks, and increasingly for analysing data through techniques such as AI and machine learning (see eg Porter 1995; Callon and Muniesa 2005; Miller 2001). It also includes architecture (both hard architecture of the built environment and 
'soft' architectures of codes or algorithms (Lessig 2009; Yeung 2018)); 'technology' in the sense of digitally enabled techniques such as smart contracting or smart rules; information and communication, and techniques for 'nudging' behaviours as well as for directing them.

Any of these can be combined in a myriad of ways. Moreover, methods of regulation can also be objects of regulation. So, for example, regulation can be focused on market or organisational structures and processes as well as on individual behaviours, and regulators can use each of these to pursue the regulatory project. Equally, regulation can both deploy and seek to regulate methods of calculation (eg of prices, risks, correlations), methods of physical design or methods of scientific investigation. The debates on which regulatory techniques to use is important to understanding how effectively regulation can achieve its goals, but focusing on techniques to the exclusion of the other dimensions of a regulatory system risks over-simplifying the challenges of achieving those goals, over-looking the politics involved in their selection and design, and under-playing the normative goals of regulation and its need for trust and legitimacy.

\section{Organisational Dynamics, Structures and Processes}

The fourth element of the framework are the structures, processes, capacities and motivations or cultures of the organisational actors within the regulatory system, and between systems. Understanding the interaction of institutional structures with behaviours, and organisational behaviour more generally, are sub-disciplines in their own right. In the context of regulatory systems, much of the research to date has focused on the interactions between regulators and regulatees in the context of compliance and enforcement, and on how firms respond to regulation (for review see Gunningham 2010). The internal dynamics of regulators are just as important, including how they are organised and how they prioritise (see eg Black and Baldwin 2010). Furthermore, multiple other actors can be involved in the interactions and 'regulatory conversations' which play an important role in constituting regulatory systems, including intermediaries such as certifiers, insurers, auditors, consultants, and others (Black 2002; Black 2003; Abbott, Levi-Faur and Snidal 2017). Those undertaking any regulatory functions require the capacities and associated resources necessary to undertake those functions, both material and human (funding, expertise, organisational systems and processes, the ability to learn), as well as legal, social and political capacity. Those who are auditing compliance require different capacities to those who are setting the rules or imposing sanctions for their breach, for example. Organisational actors also need the motivation or internal culture to use those capacities to further the goals of the regulatory system, which may not necessarily align with their own interests (Scott 2001; Black 2003).

Further, as noted above, the design of organisational structures and processes can itself be a regulatory technique, for example by requiring certain structures of corporate governance, or the allocation of certain regulatory responsibilities to clearly identified individuals, or the adherence to certain safety procedures. Such 'mandated self-regulation' has been a feature of health and safety regimes for decades, for example. But, again, it is only as effective as the internal management and control systems themselves (see eg Ayres and Braithwaite 1997), and the trust that regulators and others can place in firms fully to 
embed such systems not just in their processes but in their organisational goals as well (see eg Coglianese and Lazer 2003; Gunningham and Sinclair 2007).

The design and operation of the institutional architecture of a regulatory system can also be a form of regulatory technique. Debates can be specific to particular domains (eg the advantages and disadvantages of different organisational structures for financial regulation, or competition, or digital services). Or they can focus on more generic questions about the design of regulatory agencies and the nature and degree of their independence from government (eg Thatcher 2002; Gilardi 2009) and from those they are regulating. Regulatory architecture is also the focus of discussions on the roles and relationships of state and non-state regulators in multi-level governance systems, where regulatory organisations operating at the global, regional, national and/or sub-national level interact in more or less coordinated ways (eg Bache et al 2016). Relatedly, there is a growing interest in the interactions between regulatory systems, both state and non-state (eg Eberlein et al 2014). Relations may be organised through markets, networks or hierarchies (Powell, 1990), and may be exploited by powerful actors to avoid regulation, or adjusted to empower marginalised groups (see Wood et al 2019). Finally, as noted above, the architecture of experimental governance also provides a good example of the strategic use of system design as a regulatory technique, which in this case is argued by proponents to facilitate experimentation whilst satisfying political demands for subsidiarisation and autonomy (Sabel and Zeitlin 2008).

\section{Behaviours}

The operation of regulatory systems is also fundamentally dependent on the behaviours of those constituting them or interacting with them. The behaviours of those being regulated have been the subject of the compliance and enforcement literature for some time. The role of organisational leaders, of compliance and safety officers, of operational personnel and their inter-relationships are key areas for analysis: for example, how does the compliance function gain influence over the business; when are safety officers' concerns overridden in pursuit of 'getting the job done'; and what role does leadership play in driving the adoption of regulation (see eg Gunningham 2010).

Regulators' own perceptions of how people will respond to regulatory interventions, whether they are regulatees, consumers or others, is also significant, and depends on their own cognitive frameworks for analysing behaviour. Over the last twenty years or so, the economic model of the rational actor has gradually given way to more nuanced understandings of behaviour, and behavioural psychologists and anthropologists are increasingly being called on by regulators seeking to understand the different behaviours of people in both market and non-market contexts. How they behave on-line, for example, or how they respond to risk warnings, such as those issued in extreme weather conditions, or as part of the management of Covid-19.

How regulators themselves behave is also a critical question. Again the rational actor model has been influential in the regulatory literature, with the assumption that all regulators will be seeking to pursue their own preference. That is, they will either be seeking to build up their own bureaucratic empires, and/or they will be seeking jobs in the regulated sector and so will be captured by the industry (eg Levine and Forrence 1990). In 
contrast, more sociologically rooted analyses adopt a less transactional and more relational approach. Research into the interactions of regulators, regulatees and others within the regulatory system, such as consultants and legal advisors, shows how the regulatory system is constituted and co-created through those interactions, or 'regulatory conversations', in the processes of interpreting, implementing and negotiating compliance with regulatory rules (eg Gilad 2014; Black 2002; Ayres and Braithwaite 1992). Cognitive psychology is also introducing a deeper understanding of behavioural biases which can be relevant in the regulatory context (see eg Khaneman et al 1982; Jansen and Aelen 2015). When taken together with the organisational dynamics, which drive decisions on issue selection and prioritisation, these insights can offer a richer understanding than pure rational choice theory of why regulators and others behave as they do.

\section{Trust and Legitimacy}

The final, and most important, element of any regulatory system is trust and legitimacy. Whether and how trust and legitimacy are bestowed and by whom is one of the foundational questions of political and constitutional theory, but it also has a sociological dimension. Legitimacy, in the sociological sense, means having one's right to govern accepted, ie perceived as legitimate, by those who are being governed, or on whose behalf one is purporting to do so (Weber 1948; Beetham 1991; Suchman 1995; Scott 2001). Statebased regulators can derive their legal right to govern, and thus their legal legitimacy, from their legal mandates. But whilst a legal mandate may be necessary, it may not be sufficient for a regulatory system to be trusted. Any regulatory system, and the myriad of organisations within it, needs to be trusted and perceived as legitimate by a critical number of legitimacy communities in order for it to function, even if it is not universally seen as legitimate (Black 2008). Legitimacy communities include those who are relying on the regulatory system to protect or support them, for example as producers, citizens or consumers, as well as those it is seeking to regulate.

In democratic systems, there are generally four broad sets of core legitimacy and accountability demands which are usually made by such legitimacy communities, in different combinations (Black 2008). First, claims based on what may be loosely termed 'constitutional values', such as the rule of law, procedural fairness, and accountability. Second, claims based on normative values, aligned with the goals the regulatory system is trying to achieve, such as the attainment of justice, ethics, environmental sustainability or the management of risks. Third, claims based on democratic values, such as dialogue, participation, representation, and - again - accountability either directly to the demos or to those who have been elected to act on its behalf. Finally, there are claims based on functional performance such as effectiveness, expertise, and efficiency. It is important to note that these demands can be made of both state and non-state regulators. Further, in each case, the demands of each group or legitimacy community can pull in different directions. So maintaining trust and legitimacy is an ongoing task requiring transparency and continual engagement, and it is a particularly difficult one in the context of managing risks, as has been illustrated by the Covid-19 pandemic. However, regulators may need for the purposes of their own survival and functional effectiveness to pay attention to some legitimacy communities more than others, which again raises issues of exclusion of less 
powerful groups. The legitimacy and accountability relationships of non-state regulators, particularly those operating transnationally, can be even more complex, but equally have to be actively created.

\section{Summary}

The interpretive analytical framework provided here enables us to analyse systematically each part of any regulatory system. It is by its nature an artifice which separates out for independent analysis elements which are interdependent in their operation. It is also selective - dynamics such as power and discourse pervade these different elements, for example, but are not drawn out here for separate consideration. Often, an analysis of any particular regulatory system will focus on one or two elements. Whilst that is a practical approach - not every analysis of regulatory systems has to cover every element - it does need to be cognisant of their existence and relevance. If we are really to understand the dynamics of any regulatory system we cannot understand the nature and dynamics of any one element in isolation from its interaction with the others, nor can we read from the study of one element how the dynamics of the whole system do or are likely to operate. Further, it is important to understand that any one regulatory system does not exist in isolation but frequently operates in interaction with other systems, in important and complex ways. The analytical framework provided here enables us to understand the dynamics of regulatory governance systems, both as observers and as participants. It can also help us to analyse deep-rooted causes of failures and to think through the potential impacts of changes in any part of the system. Critically for this discussion, it provides the groundwork for the next stage of the analysis.

\section{CONSTITUTIONALISING REGULATORY GOVERNANCE SYSTEMS}

In the discussion which follows, the analytical framework set out above will be used to analyse how constitutional governance systems, as forms of regulatory governance systems, can constitutionalise regulatory systems in the sense of ensuring that they operate in accordance with constitutional norms and values.

What is involved in conceiving constitutional systems as a particular form of regulatory governance systems? Extending the analysis of polycentric regulatory systems set out above, constitutional governance systems (of which law is one element) are a dynamic and continually evolving set of norms, values and practices (even if their written texts remain unchanged) which express the constitutive and the regulative aspects of the relationship between the governing and the governed (see also Loughlin 2003). Their participants, as individuals and organisations, are active in the system's evolution, which means that the institutional architecture, too, will vary in its polycentricity, ie in the degree of dispersal and fragmentation of actors in the system, in their degree of internal coherence, and in the extent to which their roles are clearly delineated. Further, those individuals and institutions participating will have different normative or value frameworks, cognitive frameworks, different capacities for action, and different degrees 
of power and/or authority, all of which can affect their behaviours and their interactions with others. Finally, all those entities comprising and participating in the constitutional governance system have actively to maintain their legitimacy for the system to survive and function effectively.

The term 'constitutionalising' is thus being used below to refer to what is being constitutionalised (eg organisations), and to how different elements of the system may be constitutionalised (eg by organisations). However, although for reasons of presentation and brevity each element is presented as aligned, in using the analytical framework it is important to remember that each element of each system is potentially in constant interaction with every other element of that system - it can act on it and be impacted by it. Equally, it is important to understand that there is no necessary and direct relationship between the application of an element in one system and its 'twin' in the other - regulatory organisations can be constitutionalised not just through the constitutionalising effects of other organisations but also by behaviours, techniques and so forth. Further, there is no necessary direct and linear relationship in which the constitutional system unilaterally 'dominates' the operation of the regulatory system. Notwithstanding the hierarchy of legal norms it is analytically possible for the two systems to have a reflexive relationship in which each shapes and is shaped by the other, though whether and how they do so is an empirical question to be explored on a case by case basis. Finally, although it is often the case that regulatory systems have hybrid public and private elements, or can be completely non-state based, for the sake of simplicity the analysis in this article is confined to the statebased elements of regulatory systems.

We can start the analysis at any point in the framework, but for the sake of symmetry with the exposition above, the same ordering is used here.

\section{Constitutionalising Goals, Purposes and Values}

In principle the barest definition of a constitution is to provide an allocation of powers and functions to different institutions of the state, and to provide the rules which both constitute those institutions and set the parameters for how they operate (Raz 1998). For some theorists, it is additionally to encode, or otherwise express, norms and values which those institutions must observe in the exercise of their powers and functions. Norms which may or may not be included in the written text of the document or documents comprising the constitution, or which may be derived from the wider legal system in which the constitution is embedded, or may be generated endogenously through the practices of the institutions of the state and those who occupy them. For others, constitutions provide the framework of relations between those in pursuit of a commonly shared enterprise (see eg Dyzenhaus and Thorburn 2016). As Martin Loughlin clearly articulates, there are competing conceptions of the state's role: as an agent of the individuals comprising the polity, whose role it is to protect the rights and autonomy of those individuals to pursue their own conceptions of the good life (the state as societas); and as a 'pastor' or guardian whose role it is to enable the collective wellbeing of the community, providing for each the opportunities to fulfil their potential for the benefit of all (the state as universitas) though there are many variants in between (Loughlin 2003). Constitutions may also be the 
outcomes of bargains between powerful political actors, and their function includes providing a coordinating device for those political bargains to be upheld, and a stabilisation mechanism which enables them to become self-enforcing (Elkens et al 2009).

Even as outcomes of political bargains, constitutional systems can seek to ensure that in the conduct of governance certain values are upheld by the institutions of the state, including but not limited to rights of individuals and groups. Of central relevance to the project of constitutionalising regulatory systems, at least in democratic societies, are the principles of the rule of law, and the need for law (and constitutions) to secure the rightful conditions under which each can pursue their own ends compatibly with others being able to do the same (Fuller 1964; Waldron 1989; Fallon 1997; Allan 2013; Craig 2005). The debates are well known. In formal terms, laws must be clear and non-contradictory, normally prospective in effect, and published; they must additionally be fairly, consistently and impartially applied, and administered in accordance with their purposes. In substantive terms, some would add, laws should provide equal protection for all, such that rights or benefits cannot be unfairly denied.

Further, they may be values which are essential to the prudent and peaceful running of the state in a way which contains political conflicts and to ensure the maintenance of the public realm, the state, as an autonomous entity (Loughlin 2003). So principles of public law, the law relating to the activity of governing the state, such as rationality, proportionality, necessity or propriety, can derive from the practical, political reasoning based on prudential considerations and the need constantly to reconcile competing conceptions of the role of the state (ibid). Others have argued that the social and economic purposes of regulatory law and regulatory rules should be recognised in the interpretation which courts and others give to such rules, drawing on principles embedded in the constitutional settlement (Sunstein 1993). Ultimately the values which underpin, constrain, enable and are expressed in the practices of those who govern is an empirical question which varies in each constitutional system, and those values are in turn linked to the cognitive frameworks and epistemologies of those practising the constitutional system itself.

\section{CONSTITUTIONALISING COGNITIVE FrAMEWORKS AND EPISTEMOLOGIES}

In the context of constitutional governance systems, cognitive frameworks are the understandings both of those who create the constitution (if there is a single moment of creation) of its purposes and how it operates, and of those constitutional actors who continuously develop and enact constitutional practices over time. The epistemologies of a constitutional governance system are the sources of knowledge which were drawn on in its creation, and importantly those which are drawn on during its day to day performance and evolution, just as they are for other regulatory governance systems. It is important to note that neither cognitive frameworks nor epistemologies are crystallised in time. They may be expressed in the text or sources of the constitution, or in written conventions, but they can only ever be partially inscribed. Instead, the conception of constitutional systems which is consistent with that of regulatory governance systems set out above is that constitutions are dynamic and reflexive: they are being constantly interpreted, constituted 
and altered by the practices of those occupying the institutions it creates, whose actions it shapes but by whose actions it is in turn shaped as well.

Around the world, constitutions have a remarkably short life - few are more than fifty years old (Elkins et al 2009). Although Anglo-American constitutional theory is preoccupied with the US and British constitutions, looking further afield to accounts of the creation of other constitutions, particularly to resolve situations of violence or conflict, can provide fascinating insights into the issues of cognitive framing and sources of knowledge, as well as power (though this is not to argue for a particular approach to interpreting constitutional texts). For example, in the negotiation of the constitution in South Africa from 1993-1996, there were essentially two competing understandings of which was the biggest problem which the state, and thus the constitution, needed to address: ethnic conflict or social and political inequality? Different facts and sources of knowledge were brought into play to substantiate the arguments of each group. For those who saw the main problem to be that of conflict, the constitution should adopt a consociational model, with emphasis on managing conflict through a carefully crafted balance of powers between ethnic and/or regional groups with the state playing the role of a mediator. In contrast, for those who saw the major problem to be social, political and legal inequality, the constitution should adopt a justice model, with an emphasis on individual civil, political and socio-economic rights, enacted by a strong central state operating through majoritarian decision making, and upheld by the courts. The constitution which emerged was a product of many factors, but not least these different understandings of its role and purpose in the particular context of the time (Ebrahim 1999).

Shifting the focus, whilst the regulatory framework for analysis can accommodate a number of theories of constitutions, each of those theoretical frameworks has a slightly different perspective when it 'looks down' on regulatory systems. Indeed, how regulatory governance systems (state and non-state) are perceived from a constitutional perspective goes to the core of two fundamental questions in constitutional theory: the source of constitutional authority, and the role of the state. The distinction can be overstated, but it is useful to draw it out in simple terms to emphasise the different ways in which the role of regulatory agencies is viewed from these different perspectives.

For those who see the source of the state's authority to be the will of the people expressed through democratic elections, and for the state's role to be providing the conditions by which individuals can act autonomously to pursue their own versions of the good life, anything other than minimal interference in their lives by a democratically elected official is constitutionally offensive (see eg Harlow and Rawlings 2021).

Regulatory agencies can also breach the doctrine of separation of powers by combining executive, rule-making and judicial functions. Since the 1990s, the rapid growth of independent regulatory agencies in the US and the UK has introduced this particular mode of governance into constitutional and political systems, which in turn have had to adjust to accommodate them (see eg Gilardi et al 2006). Concomitantly, their development has been frequently regretted. Even the term used in political science literature to describe such bodies, as 'non-majoritarian institutions', is normatively loaded. Particularly but not uniquely in populist discourse, regulatory agencies embody the power of technocrats and 
'experts', whose narrow epistemologies and cognitive frameworks unjustifiably exclude the experiences, views and values of those who are not part of the same technocratic or scientific elite.

From this perspective, regulatory systems (and in particular independent regulatory agencies) are usually seen as presenting a classic principal-agent problem: the people (in the role of principals), through democratic elections, delegate to the executive and legislature the right to govern them (in the role of agents); in turn, the executive and legislature (in the role of agent-principals) delegate to a range of regulatory organisations and individuals (in the role of agents) the powers to address particular problems or attain particular goals. The problem is conceptualised as how to ensure that the agent does not defect or deviate in any way, and in particular does not start to act in favour of the interests of the industry they are regulating - a problem often characterised as 'regulatory capture'. Politically, especially for rational choice institutionalists, deviation from the will of the principal is seen in terms of deviation over time from the goals and purposes of the enacting coalition, whether through outright capture by strong political interests or more mundanely through 'bureaucratic drift', especially as political attention moves elsewhere, or is overturned by a new coalition (McCubbins et al 1989).

However, from the perspective of the state as a pastor, or guardian, whose role it is to act prudently for the collective good of the people, regulatory institutions can be seen as an essential part of government; if not as partners in a common enterprise, then at least as representatives of the state to whom powers have been delegated to pursue that enterprise. Their functional efficacy, then, is critical to the attainment of the pastoral project, and in no small part dependent on their being insulated to a degree from the political dynamics of the state and thus from the institutions through which political conflicts are expressed and managed: the executive and legislature. The problem, in other words, is one of regulators having sufficient independence to act as the technocratic experts they need to be to perform the functions they have been assigned with some consistency over time. Additionally, from an economic perspective, for those regulating industries or markets which are characterised by high levels of private investment, there is a need for political systems to demonstrate clear and credible commitment to a particular mode of regulation, which can be done by embedding the regulatory regime in such a way that it is difficult for a new governing party or coalition to revoke it (eg Gilardi 2009). From this perspective, the politicisation of regulators, for example through overtly politicised appointments to office or strong executive powers of direction and control, are seen as a problem not a solution.

But whether or not regulatory actors are seen as agents of government principals or participants in the performance of the collective enterprise of the state, those delegating powers to them will want to minimise 'drift' away from the task they were created to perform, and ensure they stay within their legal remits. So the political, legal and constitutional problem from these different perspectives is how to manage the tension between delegated independence on the one hand and legal and political accountability on the other - an issue to which we will return below.

A further argument is possible, however, which is that the independence of regulatory organisations is not just a functional but a constitutional necessity, as their legally mandated 
independence and operational distance from elected politicians provides them with a protective buffer from the vagaries of elected politicians. Conventionally, it is argued that it is elected politicians who take strategic benefit from this buffer, as they use it to distance themselves from the 'blame games' in times of regulatory crisis. But it can also be argued that independence protects the regulatory part of the state from the pernicious and polarising effects of politics, enabling not just credible, technically expert, and timeconsistent decisions to be made but constitutional values to be realised also, and especially, when they are being challenged, or indeed flouted, by those in the political institutions of the executive and/or legislature. For example, Michael Lewis's account of the Trump administration's attitude to executive agencies, many of which manage significant societal risks, suggests that the structurally closer those agencies are to the state the more they are vulnerable to the damaging effects of highly partisan politics on their operation (Lewis 2018). It is not common for commentators to argue that the independence of regulatory agencies has a value in creating a haven for constitutional values to be upheld, but as democratic institutions have come under increasing threat from the effects of polarisation, it is one which is worth countenancing. Though of course the haven, such as it may be, is fragile: it will last only as long as any executive or legislature allows it to.

\section{CONSTITUTIONALISING TECHNIQUES}

The methods or techniques used by constitutional governance systems are themselves tools of regulatory governance. (Indeed, it is interesting to note that Elkins et al's analysis of the longevity of constitutions found that certain design techniques were prevalent in those constitutions which endured longest; so, taking into account the variable impact of external factors, there is such a thing as good constitutional design (Elkins et al 2009).) Constitutionalising techniques therefore include all the methods noted above, such as legal and non-legal norms governing the behaviour of regulatory officials and the operation of regulatory processes, the design of organisational and institutional structures, and the management of regulatory capacities, including staffing and budgets, and accompanying systems of monitoring and enforcement.

One of the critiques of the 'new governance' techniques of regulation noted above is that they are difficult to constitutionalise. The contrast with 'command and control' style regulation can be over-stated, but it is the case that such techniques deliberately involve greater delegation of powers to regulators to regulate ever more technically complex issues, and thus greater discretion and ability to constitute the regulatory system in ways which the legislature and core executive cannot control, or at least not to the same degree. Newer technologies of regulation are posing even bigger challenges, in particular the growing use of AI and machine learning techniques to monitor behaviours and identify potential suspected non-compliance (see eg Yeung 2018), and it is likely that other developments, such as the creation of machine readable rules which auto-implement, will only enhance them.

But no matter what techniques or approaches are being used, it is an inescapable fact that the main actors in constitutional governance systems cannot easily monitor the day to day decisions of the regulators to whom they have delegated powers, just as regulators 
cannot easily monitor the day to day decision making of those they regulate. As the regulatory state has grown in size and complexity and as regulatory technologies have become more diverse, the use of constitutionalising techniques, such as the design of organisational structures and the regulation of regulatory processes, becomes more intense. In particular, there has been an accompanying plethora of codes, both legal and non-legal, which seek to regulate regulatory processes and set out how regulators should develop, implement and enforce regulatory requirements. They can include, for example, requirements to consult on new regulatory proposals, to conduct cost benefit analysis and/or regulatory impact assessments, to act in a manner which is efficient, targeted and proportionate, and to explain how regulators will use their enforcement powers. They may also include the requirement for post-implementation reviews or sunset clauses, though these are less common. Such provisions may be cross-cutting requirements which apply to all regulators, or they may be specific to individual regulators (see eg OECD 2018).

Other methods for constitutionalising regulatory systems include the design of organisational structures of regulatory organisations and appointment of key personnel by the executive and/or legislature. As noted above, within constitutional systems based on the separation of powers, the extent to which regulators combine rule making, implementation and enforcement powers can present a challenge to the values of the constitutional governance system. And no matter what those values are, the design of organisational structures and appointment of key personnel can be used for more political reasons. Funding can also be an important method of controlling a regulatory organisation and can be used as a political as well as a constitutional tool of control (Hood, 1983). Indeed, the degree to which regulators are bounded in practice can have much more to do with executive control over budgets and staffing than with the definition of their formal legal powers - and it can become a matter of real debate if the executive or legislature seeks to truncate the capacity of regulators to fulfil their roles through such indirect means, rather than through legislative changes to their purpose and scope (see eg Lin 2019).

\section{CONSTITUTIONALISING ORGANISATIONS}

As noted above, the organisational structures, processes, capacities and motivations or cultures of organisations within the regulatory system are key to its dynamics; by the analogy pursued here, the same is true for constitutional governance systems. Analysing the dynamics of the political and legal institutions of the state is a core subject in its own right, but it is their interaction with regulatory governance systems which is in focus here. We have seen that for elected politicians, for example, a core political motivation driving this interaction can be to prevent regulators from moving too far away from their own political agendas.

It is the role of the courts in constitutionalising regulatory governance systems which goes to the heart of different conceptions of the constitutional governance system itself. This is unsurprising, for the appropriate role of the judiciary in the continual process of defining, interpreting and/or upholding the boundaries of the powers of the other institutions of government, or the values which they should observe, is one of the central debates in constitutional discourse, and the central pole around which conceptions of 
constitutions and of the role of the state revolve. Broadly speaking, those who advocate for a rights-based conception of the constitution, particularly if the sources of those rights are found in common law (in common law systems), argue for a more interventionist role for the judiciary to ensure that those rights are upheld by the state and individuals are protected from unwarranted state intervention. In contrast, those who advocate for a functionalist conception of the constitution, and a 'guardianship' role of the state as leader and governor of the common enterprise, argue for a less interventionist role. They favour a greater margin of discretion for regulatory actors to pursue the tasks they have been charged with, using their technical expertise and specific decision processes which are more suited to making the multiple trade-offs which are often involved in regulatory decision making where competing goals have to be pursued. It is not surprising, therefore, that most legal debates on constitutionalising regulatory systems revolve around competing theories of judicial review, and that courts are in the front line of efforts to constitutionalise not just regulatory agencies but their relationship with other branches of government, including requiring agencies to act in accordance with constitutional principles in the face of executive directives to the contrary (Harlow and Rawlings 2021).

Turning to the role of the legislature and executive in constitutionalising regulatory systems, observing that there is a tension between the independence of regulators and their accountability to the legislature and executive is neither new nor surprising. Moreover, some constitutional governance arrangements are more accommodating of independent regulatory agencies than others. There have been various attempts to 'score' the independence of different regulators by analysing their formal relationships with the executive or other bodies of the state. In practice, however, navigating the boundaries of those critical relationships is complex, and is being constantly negotiated in the day to day performance of any state-based regulatory regime through the formal and informal interactions of regulators and their political overseers. As the head of any regulatory organisation knows, independence is as much a state of mind as it is a series of formal legal or even political arrangements.

Furthermore, the complexity of the regulatory landscape and the technical nature of the regulatory function can pose a significant challenge to the capacities of a legislature or executive to ensure that regulators are acting appropriately. Hence the creation of a plethora of other organisations which are given a role in constitutionalising regulatory systems. These may include central 'better regulation' units, national auditors or equivalent bodies who seek to regulate and/or evaluate regulators' performance, as well as ombudsmen or other complaints bodies which consider complaints by individuals against regulators' actions or decisions, in addition to courts or specialist tribunals. Ad hoc inquiries may be appointed to investigate regulatory failures. Regulatory bodies can further be subject to rules on transparency, for example through Freedom of Information legislation or equivalent, and to laws on whistleblowing (for a recent review see OECD 2018). But notwithstanding their legal powers, the capacities of accountors may remain limited, for example through lack of funding or expertise, and their actions may be uncoordinated, limiting their effectiveness in practice.

There may also be extra-national bodies involved in overseeing state-based regulators and holding them to account within particular regulatory domains. These bodies may have 
a legal mandate to exercise such functions, as within the EU system of regulation where the Commission or special regulatory bodies have powers to oversee the performance of national regulators, and to take legal action against member states for non-compliance. Or there may be no legal mandate as such, but the role of a transnational body is recognised and accepted by the national government, as in the system of global financial services regulation where governments agree to abide by principles of regulatory design which are imposed by a transnational body, the Financial Stability Board, and monitored by the international institutions of the IMF and World Bank.

But the ability of any other organisations, whether national or extra-national, to play a role in constitutionalising regulatory systems is dependent on their own capacities, resources and motivations. Moreover they may be dependent on the willingness of other actors who have constituted them (such as the executive in national constitutional systems, or those involved in constituting extra-national actors) to give them the capacity to be effective in their efforts to constitutionalise a regulatory system. For example, the executive may deny them adequate financing or information, or it may also have 'stacked the deck' of other constitutional actors such that they act in accordance with the interests of the governing elite, for example through exercise of the executive or legislature's power over appointments to key bodies such as the courts. Or with respect to global regulatory actors, different states may be unwilling to cede much effective power to the extra-national regulator to scrutinise the performance of their own national regulators, and even less willing to accede to demands that regulatory organisations be constituted in a particular way, such as requiring that regulators are given independent rule making or enforcement powers. The role of either national or extra-national actors in constitutionalising national regulators (as opposed to assessing their functional efficacy) can therefore be limited. So, whether or how the organisations in the constitutional governance system can and do play a role in constitutionalising regulatory systems is as dependent on the structures, processes, capacities and motivations of those organisations themselves as it is on the extent to and manner in which the regulatory system responds.

\section{BEHAVIOURS}

Organisational structures, processes, cultures and capacities are intrinsically linked to the behaviours of organisations and the individuals within them. Central to the conceptualisation of the state as a separate system from the rest of society (and thus the public from the private), is the requirement that individual office holders within the state separate their conduct in public office from their private interests, so as not to abuse their powers and to serve the public good (see eg Pettit 1997). Concomitantly, there may be rules protecting officials from individual legal liability in the proper exercise of their powers.

Constitutionalising the behaviours of individual officials and of the institutions established by the constitution thus means ensuring that they stay within the roles allocated to them and that they act in accordance with constitutional values. However, although legal constitutions can place formal limits on powers, there is nothing exceptional in observing that the lived practice of any constitutional governance system, as with any 
regulatory system, is dependent on the behaviours of those exercising those powers. Public choice theorists, for example, have long argued that elected politicians treat regulatory laws as goods which can be traded in the electoral marketplace, with favourable laws being 'sold' to the highest bidder (Mueller 2003). The argument can be over-stated and over-generalised, but the overall point remains: elected politicians can use their powers to give preference to those who are likely to re-elect them, including by enacting laws which create regulatory regimes which are favourable to their interests.

Recently, constitutional theorists and commentators have been arguing that highly partisan politics can itself put constitutional settlements under strain. Actors can play 'constitutional hardball' by pushing their constitutional powers to their limits rather than acting with tolerance and restraint, or as regulatory scholars would say, in accordance with the spirit and not just the letter of constitutional law. As Levitsky and Ziblatt argue in the context of the US presidential system: 'When partisan hatred trumps politicians' commitment to the spirit of the Constitution, a system of checks and balances risks being subverted in two ways... Under divided government, where legislative or judicial institutions are in the hands of the opposition... legislative and judicial watchdogs become partisan attack dogs... Under unified government, [they can transform] from watchdog into lapdog', paving the way for authoritarian rule (Levitsky and Ziblatt 2018, 126).

In turn, the manner and extent to which constitutional actors will seek to constitutionalise the behaviours of regulatory actors is dependent on their motivation and capacities to do so. As noted above, constitutional systems can use a range of regulatory governance techniques for monitoring and sanctioning regulators' and regulatory bodies' behaviour, such as through provisions on conflicts of interest, transparency and reporting requirements, including in some cases requirements for meetings of their boards to be made public; audits, inquiries, and performance evaluations; and complaints and dispute resolution procedures, including ombudsmen and dedicated compensation systems. Sanctions on individuals vary and may include dismissal; and for a regulatory organisation, the ultimate sanction is that it is abolished.

But no rule is self-enforcing and, from a constitutional perspective, the behaviours of regulators and regulatory bodies are often problematised in terms of how to manage the discretion they inevitably have in exercising the powers delegated to them. We may look to the plethora of legal and other institutional arrangements in place to regulate regulators, but ultimately understanding whether and how their behaviours are constitutionalised in practice requires deep engagement with their day to day decision making. It also requires deep theoretical understanding of the interactions of institutional structures and processes with organisational and individual behaviours, and thus demands an interdisciplinary approach, and there is a wealth of regulatory literature which explores the behaviour of regulatory officials and organisations drawing on multiple theories, including those of rational, sociological or historical institutionalism (eg Scott 1995). More recently, cognitive psychology draws attention to decision making biases and to 'cognitive capture', that regulators may regulate in favour of regulatees because they share a common cognitive framework and rely on the same sources of knowledge to inform their decisions (Black 2013a). Further, it may be that some regulatees are simply more adept at navigating the regulatory system than others and thereby gain advantage, for example because they have 
employed former regulatory officials who spend the 'bureaucratic capital' they have accumulated to gain employment in the industry. It may also be that political pressure is imposed on regulators not to take stringent action. Or the design of the regulatory system is such that it favours one sector of industry or one set of goals over another, or is interpreted as doing so by regulators (see eg National Commission 2011). The overall result may be the same as public choice theorists would predict (regulators will favour some or all regulatees), but for very different reasons.

The constitutional actors charged with overseeing regulators and making them accountable can have some impact on the behaviours of regulators. Studies of the impact of judicial review, for example, indicate that cases do have an impact on the internal structures and processes of regulatory organisations (Halliday 2004). Inquiries into specific regulatory failures can lead to operational changes, to the addition or removal of powers, and indeed to the abolition of certain regulators and a creation of new ones. Research has also explored how the day to day 'constitutionalising' activities of ombudsmen, legislative committees, audit offices and so forth impact on the day to day behaviours of regulators (see eg Harlow and Rawlings 2021). But ultimately, the extent to which constitutional overseers, regulatees and the wider public perceive regulators and the regulatory system to be acting in line with constitutional goals and values comes down to trust.

\section{TRUST AND LEGITIMACY THROUGH CONSTITUTIONALISATION}

In turning to consider the element of trust and legitimacy in regulatory systems we come full circle, back to constitutional goals and values. From a constitutional perspective, whether or not regulators are (or should be) trusted and seen as legitimate depends on the extent to which their existence and actions are seen to be in line with constitutional goals and values, ie constitutionalised. As noted above, the assessment can be made on the basis of the values of the constitutional system in which they are embedded, or on the basis of separate, normative constitutional theories.

As noted, 'looking down' on regulatory systems from a constitutional perspective, the constitutional 'problem' of regulatory accountability is usually framed in terms of how to manage the tension between regulatory independence and legal and political control. The answer is usually sought in terms of making regulators adequately accountable. There is nothing objectionable in framing the question and answer in this way, but it tends to assume that there is a single answer across time - albeit one which is constantly elusive. More productively, it is suggested, we should recognise that regulators will necessarily act independently. And so we should frame the challenge, as here, as one of whether regulators are themselves being adequately regulated by the relevant actors within the constitutional governance system. Bearing in mind the trade-offs that will inevitably have to be made between delegation and control, and that the answer to that question is likely to be contested by different legitimacy communities and will have to be continuously reevaluated.

Further, in 'looking up' at the constitutional system from a regulatory perspective, we see that constitutional governance systems can be as polycentric as regulatory governance systems, and their interactions with their respective sets of regulatees just as complex. 
Each is trying to regulate the dynamics of complex, polycentric systems over time and at a distance, whilst themselves operating within a complex, polycentric system. As noted above, the challenges of calling regulators to account include: the scale, scope and complexity of the constitutional as well as the regulatory landscape; the number and relationship between the different constitutional and regulatory bodies involved (and their propensity to blame-shift); the technical complexity and contestability of the regulatory task; the opacity of day to day regulatory processes; and the institutional and organisational structures of willingness of the regulatee to be regulated or the accountee to be called to account. The accountability problems raised both by 'many hands' and by 'no hands' can be acute, but these apply just as much to the plethora of actors within the constitutional system of governance as they do to regulators. Moreover, as noted above, the ability of an organisation such as an audit office, legislative committee, ombudsman and so forth, and even the judiciary, to effectively regulate a regulator by calling them to account, and the consequences that it can impose, are largely dependent on its own 'accountability capacity' and the power and position that it has within the overall constitutional system.

If we consider trust and legitimacy from the perspective of a regulator, we see that whether or not they are trusted and seen as legitimate can mean more than 'just' whether they are acting in accordance with constitutional values, or pursuing the collectively agreed project set out in their legal mandates. As noted, regulators face legitimacy demands from multiple legitimacy communities, of which constitutional actors are but one. Others include those they regulate and the public on behalf of which they purport to regulate. But 'the public' does not speak with one voice, and in particular as populism rises, so does discontent with the rule of technocratic experts which regulators embody. So the legitimacy demands which are made of regulators by all these various communities are multiple and often competing.

It is perhaps not surprising, therefore, that regulators act positively to demonstrate their own trustworthiness, to create their own legitimacy, in order to meet the claims of these multiple communities. Just as regulatees can 'go beyond compliance', regulators can act in ways which go beyond the formal requirements of accountability placed on them. They can engage in informal as well as formal consultations, adopt greater degrees of transparency and reporting than may be required, have regular stakeholder engagement meetings, as well as a range of other measures (eg Thatcher 2002; Black 2013b). However, as noted above, some of those communities are more powerful than others, leading to criticisms that regulators are captured by industry, for example, or by technocratic experts, and do not respond to more marginalised groups.

Finally, considerations of trust and legitimacy also highlight the intrinsically embedded position of regulatory systems in the social, legal and political order, and in the case of state-based systems, in the constitutional order of that state. State-based regulatory systems can draw on the legitimacy of the constitutional system in which they are embedded, but only to the extent to which they are perceived, and trusted, to be acting consistently with it. And if the state, or some of its core institutions, is not trusted and seen as legitimate, it is unlikely that its regulators will be either. 


\section{CONCLUSION}

In principle, therefore, there is a relatively straightforward set of answers to the question of how regulatory systems are constitutionalised. Where regulatory systems are constituted by the state, the norms and values to which regulators are to conform may be set out in the constitution, elaborated in legislation, in case law, and/or in the day to day procedures and practices of those occupying the institutions of the state. The constitution and accompanying norms also provide the mechanisms by which those norms and values are imposed and enforced. Further, although not explored here, where they are not constituted by the state but are operating within a legal system, it is often the norms of private law which provide the principal legal requirements and mechanisms for their imposition, though there may be some porosity between public and private law systems, such that public law will recognise the non-state-based regulatory system as 'public' and thus subject to public law norms and mechanisms. Alternatively, or in addition, private law and public law may echo one another in the norms each imposes in its different sphere of operation. Where regulatory systems are operating in a transnational context, where there may be no basis to their powers in state or international law, these systems invent their own constitutions (loosely described) and accompanying normative and regulative requirements for their operation, as well as practices which imitate those of state-based regulators, in order to meet various legitimacy demands made on them.

In practice, even for state-based regulators, the inter-relationship between a regulatory governance system and the constitutional system in which it is embedded is complex. Looking 'up' at constitutional governance systems from a regulatory perspective, constitutions have been conceived here, at least in part, as systems for political as well as legal ordering. They have both constitutive and regulative dimensions, governing both the central constitutional actors, such as the judiciary, legislature and executive, as well as other actors involved in regulating regulators. As to their relationship with regulatory systems, it has been proposed that we can think of a constitutional governance system as both constituting and regulating a regulatory system through the goals and values each seeks to pursue, the techniques, organisations and individuals through which each acts, the particular sets of ideas or cognitive and epistemological frameworks those actors bring, and with a continual need both for, and in constant pursuit of, trust and legitimacy in the eyes of those on whose behalf they purport to govern.

\section{BIBLIOGRAPHY}

Abbott, K. W., Levi-Faur, D. and Snidal, D. (2017). Theorizing Regulatory Intermediaries: The RIT Model. The ANNALS of the American Academy of Political and Social Science, 670(1), 14-35.

Allan, T. R. S. (2013). The Sovereignty of Law: Freedom, Constitution, and Common Law. Oxford: Oxford University Press. 
Ayres, I., \& Braithwaite, J. (1992). Responsive Regulation: Transcending the Deregulation Debate. New York: Oxford University Press.

Bache, I., Bartle, I., \& Flinders, M. (2016). Multi-level Governance. In Ansell, C. \& Torfing, J., eds. Handbook on Theories of Governance. Cheltenham: Edward Elgar Publishing.

Baldwin R. and Black, J. (2010). Really Responsive Risk Based Regulation. Law and Policy, 32(2), 181-213.

Baldwin, R., Cave, M., \& Lodge, M. (2010). The Oxford Handbook of Regulation. Oxford: Oxford University Press.

Baldwin, R., Cave, M., \& Lodge, M. (2012). Understanding Regulation: Theory, Strategy, and Practice. Oxford: Oxford University Press.

Beck, U. (1992). The Risk Society. London: Sage Publications.

Beetham, D. (1991) The Legitimation of Power. London: Macmillan.

Black, J. (2001). Decentring Regulation: Understanding the Role of Regulation and SelfRegulation in a "Post-Regulatory" World. Current Legal Problems, 54(1), 103-146.

Black, J. (2002). Regulatory Conversations. Journal of Law and Society, 29(1), 163-196.

Black, J. (2003). Enrolling Actors in Regulatory Systems: Examples from UK Financial Services Regulation. Public Law, 63-91.

Black, J. (2013a). Reconceiving Financial Markets - From the Economic to the Social. Journal of Corporate Law Studies, 13(2), 401-442.

Black, J. (2013b). Calling Regulators to Account: Challenges, Capacities and Prospects. In Bamforth, N. \& Leyland, P., eds. Accountability in the Contemporary Constitution. Oxford: Oxford University Press.

Bovens, M. (2012). Analysing and Assessing Public Accountability: A Conceptual Framework. European Law Journal, 13, 447-468.

Brown, M. B. (2009). Science in Democracy: Expertise, Institutions, and Representation. Cambridge, MA: MIT Press.

Callon, M. and Muniesa, F (2005). Economic Markets as Calculative Collective Devices. Organization Studies, 26(8), 1229-1250. 
Coglianese, C., \& Lazer, D. (2003). Management based Regulation: Prescribing Private Management to Achieve Public Goals. Law \& Society Review, 37(4), 691-730.

Commission on the BP Deepwater Horizon Oil Spill and Offshore Drilling (2011). Deep Water. The Gulf Oil Disaster and the Future of Offshore Drilling. Washington DC.

Craig, P. (2005). Formal and Substantive Conceptions of the Rule of Law: An Analytical Framework. In Bellamy, R., ed. The Rule of Law and the Separation of Powers. London and New York: Routledge.

Dowdle, M. (2006). Public Accountability: Designs, Dilemmas and Experiences. Cambridge: Cambridge University Press.

Dyzenhaus D. \& Thorburn, M., eds. (2016). Constitutional Law. Oxford: Oxford University Press.

Dyzenhaus, D. (2016). The Idea of a Constitution: A Plea for Staatsrechtslehre. In Dyzenhaus D. \& Thorburn, M., eds. Constitutional Law. Oxford: Oxford University Press.

Eberlein, B., Abbott, K. W., Black, J., Meidinger, E., \& Wood, S. (2014). Transnational Business Governance Interactions: Conceptualization and Framework for Analysis. Regulation \& Governance, 8(1), 1-21.

Ebrahim, H. (1999). The Soul of a Nation: Constitution-making in South Africa. Oxford: Oxford University Press.

Elkins, Z., Ginsburg, T., \& Melton, J. (2009). The Endurance of National Constitutions. Cambridge: Cambridge University Press.

Fallon Jr, R. H. (1997). 'The Rule of Law' as a Concept in Constitutional Discourse. Columbia Law Review, 97(1), 1-56.

Fuller, L. L. (1964). The Morality of Law. New Haven: Yale University Press.

Gilad, S. (2014). Beyond Endogeneity: How Firms and Regulators Co Construct the Meaning of Regulation. Law \& Policy, 36(2), 134-164.

Gilardi, F. (2009). Delegation in the Regulatory State: Independent Regulatory Agencies in Western Europe. Cheltenham: Edward Elgar Publishing.

Gilardi, F., Jordana, J., \& Levi-Faur, D. (2006). Regulation in the Age of Globalization: The Diffusion of Regulatory Agencies across Europe and Latin America. In Hodge, G. A., ed. Privatization and Market Development: Global Movements in Public Policy Ideas. Cheltenham: Edward Elgar Publishing. 
Greenwood, R., Oliver, C., Lawrence, T. B., \& Meyer, R. E., eds. (2017). The Sage Handbook of Organizational Institutionalism. London: Sage Publications.

Gunningham, N. (2010). Enforcement and Compliance Strategies. In Baldwin, R., Cave, M., \& Lodge, M., eds. The Oxford Handbook on Regulation. Oxford: Oxford University Press.

Gunningham, N. \& Sinclair, D. (2009). Organizational Trust and the Limits of Management Based Regulation. Law \& Society Review, 43(4), 865-900.

Halliday, S. (2004). Judicial Review and Compliance with Administrative Law. Oxford: Hart Publishing.

Harlow, C. (2006). Global Administrative Law: The Quest for Principles and Values. European Journal of International Law, 17(1), 187-214.

Harlow, C. \& Rawlings, R. (2021, forthcoming). Law and Administration. 4th ed. Cambridge: Cambridge University Press.

Hood, C. (1983). The Tools of Government. London: Macmillan.

Hood, C., Rothstein H., \& Baldwin R. (2001). Government of Risk. Oxford: Oxford University Press.

Jansen, R. \& Aelen, M. (2015). Biases in Supervision: What are They and How Can We Deal with Them? Occasional Studies, 13(6), 1-35. Netherlands: De Nederlandsche Bank.

Jasanoff, S. (2017). Science and Democracy. In Felt, U., Fouché, R., Miller, C. A., \& SmithDoerr, L., eds. The Handbook of Science and Technology Studies. 4th ed. Cambridge, MA: MIT Press.

Jasanoff, S., Markle, G. E., Peterson, J. C., \& Pinch, T., eds. (2001). The Handbook of Science and Technology Studies. Rev. ed. London: Sage Publications.

Jordana, J., \& Levi-Faur, D., eds. (2004). The Politics of Regulation: Institutions and Regulatory Reforms for the Age of Governance. Cheltenham: Edward Elgar Publishing.

Kahneman, D., Slovic, P., \& Tversky, A., eds. (1982). Judgment Under Uncertainty: Heuristics and Biases. Cambridge: Cambridge University Press.

Kingsbury, B., Krisch, N., \& Stewart, R. B. (2005). The Emergence of Global Administrative Law. Law and Contemporary Problems, 68(3/4), 15-61.

Koop, C. \& Lodge, M. (2017). What is Regulation? An Interdisciplinary Concept Analysis. Regulation and Governance, 11(1), 95-108. 
Krisch, N. (2010). Beyond Constitutionalism: The Pluralist Structure of Postnational Law. Oxford: Oxford University Press.

Ladeur, K-H. (2012). The Emergence of Global Administrative Law and Transnational Regulation. Transnational Legal Theory, (3)3, 243-267.

Lessig, L. (2009). Code and Other Laws of Cyberspace, Version 2.0. Google Books.

Levitsky, S. \& Ziblatt, D. (2018). How Democracies Die. New York: Broadway Books.

Lewis, M. (2018). The Fifth Risk: Undoing Democracy. Penguin UK.

Lin, A. C. (2019). President Trump's War on Regulatory Science. Harvard Environmental Law Review, 43(2), 247-306.

Majone, G. (1994). The Rise of the Regulatory State in Europe. West European Politics, 17(3), $77-101$.

McCubbins, M. D., Noll, R. G., \& Weingast, B. R. (1989). Structure and Process, Politics and Policy: Administrative Arrangements and the Political Control of Agencies. Virginia Law Review, 75(2), 431-482.

Miller, P. (2001). Governing by Numbers: Why Calculative Practices Matter. Social Research 68(2), 379-396.

Mueller, D.C. (2003). Public Choice III. Cambridge: Cambridge University Press.

Nuffield Council on Bioethics. (2016). Genome Editing: An Ethical Review. London: Nuffield Council on Bioethics.

OECD (2018). Regulatory Policy Review. Paris: OECD.

Pettit. P. (1997). Republicanism: A Theory of Freedom and Government. Oxford: Oxford University Press.

Powell, W. W. (1990).Neither Markets nor Hierarchies: Network Forms of Organization. Research in Oragnizational Behaviour, 12, 295-336.

Power, M. (1997). The Audit Society: Rituals of Verification. Oxford: Oxford University Press.

Raz, J. (1998). On the Authority and Interpretation of Constitutions: Some Preliminaries. In Alexander, L., ed. Constitutionalism. Cambridge: Cambridge University Press. 
Sabel, C. F. \& Zeitlin, J. (2008). Learning from Difference: The New Architecture of Experimentalist Governance in the EU. European Law Journal, 14(3), 271-327.

Scott, C. (2001). Analysing Regulatory Space: Fragmented Resources and Institutional Design. Public Law, Summer, 329-353.

Scott, J. C. (1999). Seeing Like a State: How Certain Schemes to Improve the Human Condition Have Failed. New Haven: Yale University Press.

Scott, W. R. (2001). Institutions and Organizations. 2nd ed. London: Sage Publications.

Scott, W. R. (1995). Institutions and Organisations. London: Sage Publications.

Suchman, M. C. (1995). Managing Legitimacy: Strategic and Institutional Approaches. The Academy of Management Review, 20(3), 571-610.

Sunstein, C. R. (1993). After the Rights Revolution: Reconceiving the Regulatory State. Cambridge, MA: Harvard University Press.

Thatcher, M. (2002). Regulation after Delegation: Independent Regulatory Agencies. Europe Journal of European Public Policy, 9(6), 954-972.

Waldron, J. (1989). The Rule of Law in Contemporary Liberal Theory. Ratio Juris 2(1), 7996.

Weber, M. (1948). Bureaucracy. In Gerth H. H. \& Wright Mills, C., eds. Max Weber, Essays in Sociology. London: Routledge.

Wood, S., Eberlein, B., Meidinger, E., Schmidt, R., \& Abbott, K. W. (2019). Transnational Business Governance Interactions, Regulatory Quality and Marginalized Actors: An Introduction. In Wood, S., Eberlein, B., Meidinger, E., Schmidt, R., \& Abbott, K. W., eds. Transnational Business Governance Interactions: Advancing Marginalized Actors and Enhancing Regulatory Quality. Cheltenham: Edward Elgar Publishing.

Yeung, K. (2010). The Regulatory State. In Baldwin, R. \& Lodge, M., eds. The Oxford Handbook of Regulation. Oxford: Oxford University Press.

Yeung, K. (2018). Algorithmic Regulation: A Critical Interrogation. Regulation \& Governance, 12(4), 505-523. 